\title{
Islamic Psychotherapy Approach In Managing Adolescent Hysteria In Malaysia
}

\section{Fariza Md Sham*}

Faculty of Islamic Studies ,Universiti Kebangsaan Malaysia(National University of Malaysia) 43600 Bangi, Kajang, Selangor, Malaysia

\begin{abstract}
Hysteria which occurs among school adolescents in Malaysia causes adverse effects on social and psychological development of adolescents. This scenario is worrying because such occurrences also interfere with the teaching and learning process. Islamic psychotherapy has its own methods in dealing with hysteria to overcome adolescent psychological and spiritual problems. Hence, the purpose of this study is to determine associated factors hysteria among adolescents and the Islamic psychotherapy approach as an early intervention process to prevent this hysteria phenomenon form occurring in schools. This research is in the form of a survey study using questionnaire as research instrument. A total of 122 school teenagers in Selangor, Malaysia are selected as respondents in this study based on hysteria experienced. Research results find that the main factor causing hysteria among adolescents is the psychological factor and the method of managing hysteria is the religious approach. On the whole, this study finds that early prevention may be implemented using Islamic psychotherapy method through the process of tazkiyah al-nafs (spiritual purification ) and riyadah al-nafs (spiritual exercise).
\end{abstract}

Keywords: Hysteria; Islamic psychotherapy; Adolescent; Psychological; Spiritual

\section{Introduction}

Hysteria is truly a social mystery, i.e., whether it is merely psychological disturbance or involves the influence of mystical elements. An individual who experiences hysteria frequently state that he feels loss of some bodily functions, and even loss of self-control. Moreover, when a person becomes hysterical, this contagious disturbance quickly spreads and afflicts a companion or group of humans physically near to him.

Hysteria is in scientific and medical terms categorised as a mental and psychiatric disease. This phenomenon is clinically analysed by the concept and characteristics referred as neurotic and somatoform disorders. In the Diagnostic and Statistical Manual of Mental Disorders IV (DSM-IV) which lists various mental disorders in psychiatric and clinical fields, somatoform or somatization disorders are divided into seven types, one of which is conversion disorder or commonly known as hysteria [1,2] Somatoform disorder is a disturbance of physical symptoms without a clear physical cause and this disorder is characterised by physical symptom (pain) without physical disease or injury. It is triggered not by biological factors but by psychological factors. This disorder may be identified by two characteristics, i.e., conversion disorder and dissociative hysteria.

Conversion disorder and dissociative hysteria are behaviours which are converted or dissociated from the subconscious such as feeling paralysed or loss of sensory functions, feeling of instability, vulnerability to influence, loss of memory, cramps of body parts and so on, which in physical reality do not exist. Similarly with symptoms like aggressive behaviour such as screaming and physically struggling to break free or attempts to injure the self or others. Thus, hysteria in Western perspective is interpreted as neurotic disturbance which is mostly caused by an individual's inner factors such emotional disturbance, emotional stress, psychological conflict and so on. Long suppressed conflict is unconsciously transformed into disturbance of body functions through hysterical behaviour [3]. The symptoms shown are psychiatric symptoms, i.e., somatic disorder symptoms characteristic of conversion disorder and dissociative hysteria.

In the Western perspective, the concept of epidemic hysteria is also discussed. Epidemic hysteria is the phenomenon of group hysteria.
Epidemic is defined as a cluster of symptoms marked by organic disease but with no identifiable symptoms. This type of hysteria occurs with two or more persons who share the same beliefs relating to the symptoms. It is synonymous with various names, including the terms mass hysteria, mass psychogenic hysteria and mass sociogenic hysteria [4]. Mass hysteria or epidemic hysteria is a global phenomenon. It has been known to also occur in other countries such as the United States, United Kingdom, Africa and Taiwan [5-7]. In Malaysia, hysteria also occurs epidemically in groups. In Malay culture and beliefs, epidemic hysteria and individual hysteria phenomena are regarded as disturbance by spiritual beings or possession by evil spirits. This view strikingly differs from the Western perspective [8]

Hysteria in Malay social beliefs in Malaysia is a symptom of being possessed by bad spirits or disturbance by spiritual beings. A part of the Malay Muslim society in the era of the 1970's to the 1990's was inclined to interpret this hysteria as bodily possession by spiritual beings [8] (Noor Eisah 1994: 20). This belief arose because of the view that hysteria which afflicted women then was a sign of disturbance by evil spirits $[9,10]$.This perception prevailed with the old generation and continues to influence the intrepretation and understanding of hysteria to this day. Even though Islam has mostly rectified this belief, hysteria continues to occur and belief in disturbance by evil spirits still holds sway [11]

Past research shows that there are three approaches in dealing with hysteria, i.e., by modern medical methods through psychiatrists, by Islamic treatment through religious healers, and by an Islamic psychological approach through Islamic psychotherapy [11]. An Islamic psychotherapy approach is preventive treatment implemented by adolescents themselves through applying spiritual and worship

*Corresponding author: Fariza Md Sham, Faculty of Islamic Studies, Universiti Kebangsaan Malaysia(National University of Malaysia), Bangi,Kajang, Selangor 43600, Malaysia, Tel: +60192746239; E-mail: farisham@ukm.edu.my

Received April 25, 2014; Accepted June 08, 2015; Published June 15, 2015

Citation: Sham FM (2015) Islamic Psychotherapy Approach In Managing Adolescent Hysteria In Malaysia. J Psychol Abnorm Child 4: 142. doi:10.4172/23299525.1000142

Copyright: ( 2015 Sham FM. This is an open-access article distributed under the terms of the Creative Commons Attribution License, which permits unrestricted use, distribution, and reproduction in any medium, provided the original author and source are credited. 
practices of Islamic teachings. Application of Islamic psychotherapy approach in the adolescent self guides him to face personal problems based on guidance from al-Quran and Hadith. The psychotherapy method which may be implemented is religious practice and purification of the soul. Muslim adolescents regularize spiritual practices decreed by God as a sign of faith in God and safeguard themselves from illegal and prohibited matters. Spiritual practices and good character (mahmudah) enable soul purification and bring peace of mind to help adolescents face various psychological and mental conflict, i.e. hysteria. There are some factors which predictably cause hysteria. The first factor which frequently underlies the occurrence of individual or group hysteria is the psychological factor of emotional disturbance and stress. This psychological factor is frequently the basis for every occurrence of hysteria [4]

Psychological factor is one of the characteristics frequently found in each hysteria occurence, in fact emotional stress, psychological conflict, anxiety, fear and panic are among emotional disturbances which lead to the phenomenon of individual or group hysteria [12]. Excessive emotional stress is one of the causes of hysteria. In many cases, there are found early signs of psychological factor or psychological stress as the beginning or basis for hysteria to happen $[13,14]$. Thus , the purpose of this article is to identify the psychological factors and methods whereby adolescents may prevent hysteria through Islamic psychotherapy.

\section{The concept of the Islamic psychotherapy}

Lately, there is an inclination on the part of psychotherapists to place religion as an important factor in the preservation and treatment of mental health. They also observed that an approach based on divinity helps to build an exceptional potential in establishing mental fortitude, patience in facing life difficulties and avoidance from restlessness and anxiety. Further, psychologists also find that the crisis faced by man today shows a need for spiritual values or religion. The holistic approach or Whole Person Counseling which stresses on the importance of religious values in life and Biblical Counseling, that is counseling based on Christian teachings, are beginning to grow rapidly. Therefore, in dealing with this development, the role of Muslim scholars and intellectuals is much needed in working together to form theories, methods and techniques of psychological treatment from the Islamic perspective. Its purpose is to bring man back to his natural self who wishes to know his Creator and understand himself as a created being.

Psychotherapy is the Western term which is popular and widely applied academically and medically in the fields of psychiatry and psychology. Thus, this article uses the term psychotherapy so that the Islamic world of psychology is in the current mainstream platform of knowledge development. This does not mean that psychotherapy did not exist in the development of Islamic psychology. In fact, the Islamic world was earlier in introducing the method of psychology such as by Ibn Sina (Avicenna), al-Kindi and Ibn Qayyim. To understand the concept of psychotherapy and its similarities with the Islamic psychological treatment method, it is necessary to discuss several definitions of the term psychotherapy in language and psychological terms. The concept of Islamic psychotherapy is not really the same concept with psychotherapy in the context of clinical psychotherapy or medication. Islamic psychotherapy is the soul of treatment of spiritual and psychological aspects [15].

In Islamic psychology, Muslim scholars have used various terms to describe about the concept of psychotherapy from Islamic perspective . Among them use the terms Tib al-nufus, 'Ilaj al-nafs, al-Tib al-ruhaniy, Tahdhib al-nufus, Tathir al-nufus, Tazkiyyat al-nafs, Tasfiyat al-nufus, Mudawat al-nufus and so on. The term Tib al-nufus or Atibba' al-nufus was used by Miskawayh in his book Tahdhib al-akhlaq. In addition, he also used the term 'Ilaj al-nafs in the same book . Ibn Qayyim al-Jawzi and Muhammad ${ }^{c}$ Uthman Najati also used the term 'Ilaj al-nafs in their books, Risalat fi amrad al-qulub [16] and Al-Hadis al-nabawi wa ${ }^{c} \mathrm{ilm}$ al-nafs.

The term al-Tib al-ruhaniy was also used by Abu Bakar al-Razi in his book al-Tib al-ruhaniy, while Ibn 'Ata' Allah ( t.t ) in his book Taj al-curus al-hawi li tahdhib al- nufus used the term Tahdhib al-nufus.

In the dictionary $\mathrm{Mu}^{\mathrm{c} j a m}$ al-wasit (t.th: 396-397), the said terms mean the same, that is, cleansing of the human soul or psyche of all vice and bad elements which damage the soul and distance them from God. Therefore, Islamic psychotherapy can be deduced as a process of treating and healing diseases which involve the physical, mental, spiritual and character .

\section{Research Methodology}

The purpose of this research is to determine the causative factors and methods of managing hysteria among victims in schools in Malaysia through an Islamic psychotherapy approach. This research is a survey study with a data collection technique by a questionnaire which uses a 5 point Likert scale to obtain information. Sampling of the research are 122 students from two secondary schools in Selangor. Criteria of the sample, is among adolescents, who have experienced hysteria and adolescents in age 15-17 years old. Their selection is based on namelists given by the schools with information on the schools from the District Education Office. The questionnaire used by the researcher has been tested earlier and the Alpha Cronbach reliability value obtained is. 897 for the psychological factor and.954 for student preventive steps in Islamic psychotherapy. The Alpha Cronbach value obtained is high, i.e. $>0.8$. The data obtained is analysed descriptively using SPSS for Windows software.

\section{Discussion of Research Results}

Based on Table 1, the aspect of emotional stress with the highest mean is "I suppress my feelings" (mean=3.14) and "I feel guilty over past mistakes" (mean $=3.12$ ) followed by hallucination or "I imagine something frightening" (mean $=3.09$ ). These three items of psychological stress obtained the highest mean for the entire psychological factors. This finding is similar to the findings by Amran and Zulkarnain (1994) and [11] that adolescents who experience mass hysteria show characteristics of suppressed feelings and hallucination of something frightening. They also feel frustrated because of guilty feelings over past mistakes. Guilty feelings over past mistakes are probably caused by bad experiences or something which they have done, about which they still have suppressed feelings. This attitude of suppressing feelings and feeling guilty in the self causes emotional stress and disturbance and is an aspect which leads to hysteria symptoms in the self.

The item "I imagine something frightening" (mean = 3.09), shows hallucination probably caused by fear and stigma of thinking about the source of hysteria which is said to be due to disturbance by spiritual beings. The emotion of fear stresses the psychological consciousness of the student and causes him to imagine the presence of spiritual beings. This finding is recorded by Tan (1963) and Teoh (1975) in the earliest hysteria occurrence in Malayisa, i.e., hysteria victims become hysterical because of extreme fear of the threat of supernatural powers present. Victims also allege seeing spiritual beings or evil spirits analysed by Tan as hallucination. Amran (1994) also finds in his study of hysteria victims that a person becomes hysterical because of fear of being possessed and thus becomes hysterical like his other friends. They imagine spirits 


\begin{tabular}{|c|c|c|c|c|}
\hline & Item & Frequency & Percentage & Mean \\
\hline 1. & I frequently experience stress or emotional stress. & 38 & $31.2 \%$ & 2.66 \\
\hline 2. & I am prone to anxiety without cause & 32 & $26.2 \%$ & 2.59 \\
\hline 3. & I become hesitant and confused in taking action/making decisions & 42 & $34.5 \%$ & 2.82 \\
\hline 4. & I am easily demoralised whenever something sad/scary happens & 53 & $43.4 \%$ & 3.07 \\
\hline 5. & I experience excessive fear & 26 & $21.3 \%$ & 2.48 \\
\hline 6. & I easily feel miserable /restless & 28 & $22.9 \%$ & 2.48 \\
\hline 7. & I feel irritable and rebellious & 36 & $29.5 \%$ & 2.63 \\
\hline 8. & I like to suppress my feelings & 55 & $45.1 \%$ & 3.14 \\
\hline 9. & I easily feel extreme sadness & 38 & $31.1 \%$ & 2.66 \\
\hline 10. & I am a very sensitive person & 38 & $31.1 \%$ & 2.73 \\
\hline 11. & I prefer to be alone & 33 & $27.0 \%$ & 2.46 \\
\hline 12. & I am easily dissatisfied over something & 37 & $30.3 \%$ & 2.62 \\
\hline 13. & I feel stressed while studying & 27 & $22.1 \%$ & 2.43 \\
\hline 14. & I feel traumatised by horrible events such as accident, death and etc & 39 & $32.0 \%$ & 2.59 \\
\hline 15. & I feel angry about something & 29 & $23.8 \%$ & 2.50 \\
\hline 16. & I have been disappointed in love & 22 & $18.1 \%$ & 2.17 \\
\hline 17. & I am disappointed in my family & 32 & $26.3 \%$ & 2.39 \\
\hline 18. & I am worried about my health & 44 & $36.1 \%$ & 2.74 \\
\hline 19. & I am dissatisfied with my physical shape & 22 & $18.0 \%$ & 2.25 \\
\hline 20. & I feel guilty over past mistakes & 54 & $44.2 \%$ & 3.12 \\
\hline 21. & I feel lonely in life & 19 & $15.6 \%$ & 2.20 \\
\hline 22. & I hate myself & 12 & $9.8 \%$ & 1.76 \\
\hline 23. & I feel ashamed with myself & 19 & $15.6 \%$ & 2.15 \\
\hline 24. & I am easily influenced by others & 29 & $23.8 \%$ & 2.48 \\
\hline 25. & I easily panic and get flustered & 44 & $36.1 \%$ & 2.75 \\
\hline 26. & I lack self-confidence & 38 & $31.2 \%$ & 2.71 \\
\hline 27. & I frequently imagine something frightening ( hallucination) & 56 & $45.9 \%$ & 3.09 \\
\hline 28. & I feel depressed and unhappy & 21 & $17.2 \%$ & 2.21 \\
\hline
\end{tabular}

Table 1: Psychological Factor.

entering their bodies to possess them. This heightened fear eventually triggers a mass hysteria.

This fear obtained a moderate mean for the item "I experience extreme fear " (mean=2.48). Muslim adolescents in a mass hysteria showed emotional disturbance of fear whether the fear already existed in them or arose at the time of hysteria. This is found by many other researchers, such as [17] that the psychological factor, feelings of fear and panic on looking at a friend afflicted with hysteria, is the cause of mass hysteria. They also find that mass hysteria may spread through a social network, i.e., hysteria symptom is transferred from one individual to another in the same group which shares feelings of fear and panic. These characteristics fulfill one of the signs of mass hysteria Bartholomew i.e., hysteria symptoms may be spread orally, visually or by sound. Dannielle also finds that in the phenomenon of mass hysteria, the psychological aspects most frequently found are emotional disturbances of fear accompanied by anxiety. The study by Amran also finds that a person becomes hysterical when he has feelings of extreme fear or sympathy on seeing his friend experiencing hysteria.

Other psychological factors which obtain a moderate mean are "I feel hesitant and confused in taking action or making decisions" (mean=2.82), "I lack self-confidence" $($ mean=2.71) and "I easily panic and get flustered" (mean=2.75). The factor of emotional stress is also a characteristic of emotional disturbance in a hysteria victim. Overall, the above psychological factors obtain a moderate mean and show characteristics and signs of psychological disturbance in a hysteria victim. The finding obtained also shows that emotional stress experienced by adolescents leads to hysteria. Thus, psychological factors may cause adolescent hysteria and are present in this phenomenon. Further, emotional disturbances frequently found among hysteria victims are feeling guilty and suppression of feelings, vulnerability to demoralization, sadness, anxiety, pressure, panic and susceptibility to influence.

The Islamic psychotherapy practice which obtains the highest mean is "Supplicate to God" (mean=3.70) followed by "Safeguard character and personality" (mean=3.50) and "Increase seeking forgiveness of God (istighfar") (mean $=3.48$ ). These practices are frequently done by students who have experienced hysteria. Further, adolescents who have experienced hysteria, less frequently "keep qiyamullail (night vigil to perform optional prayers) (mean $=2.38)$ and "Perform optional prayers such as prayers of intent (hajat) and repentance (taubat) (mean=2.52). This is based on moderate to low mean obtained for them. They also less frequently "seek Islamic treatment from an ustaz or an Islamic healer" for hysteria symptoms $($ mean=2.62). Further, a moderate mean is also obtained for other preventive steps. Infrequent practice of optional worship (sunnah ibadah) among adolescents is one aspect which influences prevention of hysteria among them.

From the Islamic psycotherapy perspective, the symptoms which can be observed are such as insomnia, restlessness, alarming stress, nightmares and so on. In addition, there are symptoms which are experienced in conscious state such as continuous dizziness, refusal to mention Allah's name, refusal to perform prayers, dreaming, forgetfulness,laziness and so on [9] state that among the symptoms shown are collapse, unconsciousness and sometimes victim is in a semi-conscious state during hysteria. And other symptoms are that 
Citation: Sham FM (2015) Islamic Psychotherapy Approach In Managing Adolescent Hysteria In Malaysia. J Psychol Abnorm Child 4: 142. doi:10.4172/2329-9525.1000142

Page 4 of 4

\begin{tabular}{|c|c|c|c|}
\hline Item & Frequency & Percentage & Mean \\
\hline 1. Perform Obligatory Prayers (Solat Fard) & 75 & $61.4 \%$ & 3.47 \\
\hline 2. Zikr (Remembrance of God) & 62 & $50.8 \%$ & 3.18 \\
\hline 3. Take ablution (Wudhuk) & 76 & $62.3 \%$ & 3.43 \\
\hline 4. Chanting Adhan (Call for Prayer) & 31 & $25.4 \%$ & 2.57 \\
\hline 5. Protect oneself by reading Quranic verses such as Ayat Kursi (Verse of the Throne) & 61 & $50.0 \%$ & 3.13 \\
\hline 6. Regularly recite al-Qur'an & 48 & $39.3 \%$ & 2.90 \\
\hline 7. Supplicate (Doa) to God & 86 & $70.5 \%$ & 3.70 \\
\hline 8. Increase seeking forgiveness of God (Istighfar) & 78 & $63.9 \%$ & 3.48 \\
\hline 9. Perform optional prayers such as prayers of intent (hajat) and repentance (taubat ) etc & 24 & $19.7 \%$ & 2.52 \\
\hline 10. Keep Qiamullail ( night vigil to perform optional prayers) & 21 & $17.3 \%$ & 2.38 \\
\hline 11. Socialize with righteous people & 40 & $32.7 \%$ & 2.84 \\
\hline 12. Seek treatment from an ustaz or Islamic healer & 30 & $24.6 \%$ & 2.62 \\
\hline 13. Avoid being alone in an isolated place & 57 & $46.7 \%$ & 3.14 \\
\hline 14. Observe propriety and taboos in a strange or lonely place such as not to make noise, not to defile or to speak nonsense & 68 & $55.7 \%$ & 3.45 \\
\hline 15. Avoid commiting vice and acts forbidden by religion & 69 & $56.5 \%$ & 3.43 \\
\hline 16. Safeguard character (Akhlaq) and personality (Sahsiah) & 74 & $60.6 \%$ & 3.50 \\
\hline 17. Practise Islamic teachings in its entirety & 69 & $56.6 \%$ & 3.43 \\
\hline 18. Properly cover up one's person (aurat) & 54 & $44.3 \%$ & 3.24 \\
\hline 19. Listen to advice from teachers and parents & 65 & $53.3 \%$ & 3.39 \\
\hline
\end{tabular}

Table 2: Preventive Steps taken by Students in Islamic Psychotherapy.

victim feels hot and cold, mind disorder, oversensitivity and irritability. It is as if the victim loses his memory due to disturbance to the brain nerves. The victim shows 'disturbance' symptoms which influence him to lose direction and lose control of his actions. At times, the victim will lose control over his movements (Table 2).

\section{Conclusion}

Hysteria which occurs among adolescents is a phenomenon in societies of all countries. Research on hysteria began since long ago and psychologists say that the main cause of hysteria is the psychological factor of emotional disturbance. However, a society which holds on to traditional beliefs attributes hysteria to disturbances by spiritual beings or evil spirits. There are different ways to deal with hysteria according to fields of expertise. Modern medicine and psychology use psychiatric methods. Islamic psychology has found a method through regularizing religious practices, i.e. in Islamic psychotherapy. This research proposes a combination of the two approaches, i.e., psychiatric approach and Islamic psychotherapy to effectively manage and prevent adolescent hysteria.

\section{References}

1. American Psychiatric \& Association (2004) DSM-IV-TR Guidebook: American Psychiatric Publication, Washington DC

2. Kasimin A, Din H (1990) Rawatan Gangguan Makhluk Halus Menurut al-Quran dan as-Sunnah:Treatment for Supernatural Disturbance according to Al-Quran and as-Sunnah, Percetakan Watan Sdn. Bhd, Kuala Lumpur.

3. Kendell R.E (1982) A new look at hysteria. Dlm. Alec Roy (pnyt.). Hysteria, hlm: John Wiley \& Sons, Ltd. New Delhi: 28-36.

4. Boss, Leslie. $\mathrm{P}(1997)$ Epidemic hysteria: A review of the published literature. Epidemiologic Reviews 19: 2.

5. Small GW, Propper MW, Randolph ET, Eth S (1991) Mass hysteria among student performers : Social relationship as a symptom predictor, The American Journal of Psychiatry $148: 1200-1205$.[

6. Bartholomew R.E, Sirois. F(1996) Epidemic hysteria in school: An International and historical overview, Educational Studies 22: 285.

7. Chen, Cheng-Sheng M.D, Yen, Cheng-Fang M.D Lin, Hsiu-Fen M.D,et al (2003) Mass hysteria and perceptions of the supernatural among adolescent girl students in Taiwan. The Journal of Nervous and Mental Disease 191: 122-
8. Tahir NEM (1994) Kajian terhadap perihal kejadian histeria di kalangan gadis Melayu: Satu pendekatan kewartawanan ,Study of Hysteria Occurrence among Malay Girls: A Journalistic Approach, Latihan IImiah. Universiti Malaya, Kuala Lumpur.

9. Kasimin A, Zakaria Z (1994) Histeria : Pencegahan dan rawatan ,Hysteria Prevention and Treatment, Dinie Publisher,Kuala Lumpur.

10. Riffin RM (1992) Histeria: Satu kajian kes mengenai pandangan orang Melayu di Bachok Kelantan Hysteria: A case study on Malay views in Bachok, Kelantan) Latihan Ilmiah. Universiti Malaya, Kuala Lumpur.

11. Fariza Md. Sham, Mohamed SN, Saparudin IF, Hamjah SH, Ismail R,et al (2012) Faktor Histeria Dalam Kalangan Remaja Sekolah The Hysteria Factor among School Teenagers. Jurnal Teknologi Social Sciences 59: 21-27.

12. Dannielle M (2007) The Role of Psychological Variables in Mass Hysteria Tesis Master. University of Canterbury, New Zealand

13. Hassan R (1991) Pengantar Psikiatri, Introduction to Psychiatry, Dewan Bahasa dan Pustaka, Kuala Lumpur.

14. Mohamed MN (2001) Pengantar Psikologi Satu Pengenalan Asas kepada Jiwa dan Tingkah laku Manusia,Introductory Psychology: A Basic Introduction to Human Psyche and Behaviour, Dewan Bahasa dan Pustaka, Kuala Lumpur.

15. Muhamad SN (2011) Islamic Psychotherapy Perspective Miskawaih. PhD Thesis, The National University of Malaysia.

16. Small GW,Nicholi (1982) Mass hysteria among schoolchildren : Early loss as a predisposing factor, Archives of General Psychiatry 39: 721-724.

17. Small GW,Feinberg DT, Steinberg D, Collins M.T (1994) A sudden outbreak of illness suggestive of mass hysteria in school children, Arch Fam Med 3: 711-716. 